\title{
Protocol
}

\section{Isolation of Mitochondria from Tissue Culture Cells}

\author{
David A. Clayton ${ }^{1}$ and Gerald S. Shadel ${ }^{2,3,4}$ \\ ${ }^{1}$ Janelia Farm Research Campus, Howard Hughes Medical Institute, Ashburn, Virginia 20147-2408; ${ }^{2}$ Department \\ of Pathology, Yale University School of Medicine, New Haven, Connecticut 06520-8023; ${ }^{3}$ Department of Genetics, \\ Yale University School of Medicine, New Haven, Connecticut 06520-8023
}

\section{MATERIALS}

The number of mitochondria per cell varies substantially from cell line to cell line. For example, human HeLa cells contain at least twice as many mitochondria as smaller mouse $\mathrm{L}$ cells. This protocol starts with a washed cell pellet of $1-2 \mathrm{~mL}$ derived from $\sim 10^{9}$ cells grown in culture. The cells are swollen in a hypotonic buffer and ruptured with a Dounce or Potter-Elvehjem homogenizer using a tight-fitting pestle, and mitochondria are isolated by differential centrifugation.

\section{Reagents}

It is essential that you consult the appropriate Material Safety Data Sheets and your institution's Environmental Health and Safety Office for proper handling of equipment and hazardous materials used in this protocol.

RECIPES: Please see the end of this protocol for recipes indicated by $<R>$. Additional recipes can be found online at http://cshprotocols.cshlp.org/site/recipes.

Equipment

Cell pellet derived from $1-5 \times 10^{9}$ tissue culture cells

MS homogenization buffer $(1 \times$ and $2.5 \times)<\mathrm{R}>$

MS homogenization buffer is an iso-osmotic buffer used to maintain the tonicity of the organelles and prevent agg/utination.

RSB hypo buffer $<\mathrm{R}>$

RSB is a hypotonic buffer used for swelling tissue culture cells.

Centrifuge tubes

Dounce homogenizer $(15 \mathrm{~mL})$ with a tight-fitting B pestle or Potter-Elvehjem homogenizer $(5 \mathrm{~mL})$ with a Teflon pestle (see Steps 1 and 3)

Phase contrast microscope

\footnotetext{
${ }^{4}$ Correspondence: gerald.shadel@yale.edu

(C) 2014 Cold Spring Harbor Laboratory Press

Cite this protocol as Cold Spring Harb Protoc; doi:10.1101/pdb.prot080002
} 
The solutions, tubes, and homogenizer should be prechilled on ice. All centrifugation steps are at $4^{\circ} \mathrm{C}$.

1. Resuspend the cell pellet in $11 \mathrm{~mL}$ of ice-cold RSB hypo buffer and transfer the cells to a $15-\mathrm{mL}$ Dounce homogenizer.

Alternatively, as described by Frezza et al. (2007), resuspend the cell pellet in $9 \mathrm{~mL}$ of ice-cold RSB hypo buffer and transfer $3 \mathrm{~mL}$ of the cells at a time to a 5-mL Potter-Elvehjem homogenizer with a Teflon pestle.

2. Allow the cells to swell for 5-10 min. Check the progress of the swelling using a phasecontrast microscope.

3. Break open the swollen cells with several strokes of the B pestle. For each stroke, press the pestle straight down the tube, maintaining a firm, steady pressure.

If a Potter-Elvehjem homogenizer is used in Step 1, then break open the cells with the Teflon pestle rotating at $\sim 1600 \mathrm{rpm}$.

4. Check the degree of homogenization with a phase-contrast microscope.

Naked nuclei (smooth spheres with obvious nucleoli inside), smaller organelles (dark, granular objects), and a small number of unbroken cells (large spheres with a granular appearance) should be present if cell lysis was successful. Eight to nine naked nuclei for every whole cell is a very good result. Trying for anything better usually results in increasing the number of damaged nuclei, which increases the number of mitochondria trapped in the nuclear pellet during the first centrifugation.

See Troubleshooting.

5. Immediately add $8 \mathrm{~mL}$ of $2.5 \times \mathrm{MS}$ homogenization buffer to give a final concentration of $1 \times \mathrm{MS}$ homogenization buffer. Cover the top of the homogenizer with Parafilm and mix by inverting a couple of times. (Save a portion of the homogenate if marker enzyme assays are to be performed later.)

6. Transfer the homogenate to a centrifuge tube for differential centrifugation. Rinse the homogenizer with a small amount of $1 \times$ MS homogenization buffer and add it to the homogenate. Bring the volume to $30 \mathrm{~mL}$ with $1 \times$ homogenization MS buffer.

7. Centrifuge the homogenate at $1300 \mathrm{~g}$ for $5 \mathrm{~min}$ to remove nuclei, unbroken cells, and large membrane fragments.

8. Pour the supernatant into a clean centrifuge tube.

The top of the pellet will be loose, so be careful not to collect it with the supernatant.

9. Repeat Steps 6 and 7 two more times.

10. Transfer the supernatant to a clean centrifuge tube and pellet the mitochondria at $7,000 g-17,000 g$ for $15 \mathrm{~min}$.

11. Discard the supernatant and wipe out the inside of the tube with a Kimwipe.

12. Wash the mitochondria by resuspending the pellet in $1 \times$ MS buffer and repeating the $7,000 \mathrm{~g}-$ $17,000 \mathrm{~g}$ sedimentation.

This wash is not necessary if a density gradient will be performed (see Protocol: Purification of Mitochondria by Sucrose Step Density Gradient Centrifugation [Clayton and Shadel 2014]).

13. Discard the supernatant and resuspend the pellet in a buffer suitable for subsequent work.

The mitochondria can be stored at $-80^{\circ} \mathrm{C}$ for at least $1 \mathrm{yr}$ for some purposes (e.g., protein isolation).

Problem (Step 4): Too many or not enough cells have lysed.

Solution: Homogenization works best if the cells are resuspended in at least $5-10 \times$ the volume of the cell pellet and if the cell suspension occupies at least half the volume of the homogenizer. Homogenization should be performed as quickly as possible because it is performed in a hypotonic buffer. The 
Dounce homogenizer disrupts swollen tissue culture cells by pressure change. As the pestle is pressed down, pressure around the cell increases. When the cell slips past the end of the pestle, the sudden decrease in pressure causes the cell to rupture. If the pestle is very tight fitting, there may be some mechanical breakage as well. If an excessive number of strokes are needed for good cell breakage, a tighter-fitting homogenizer is needed.

\section{DISCUSSION}

This basic protocol can be modified to suit special purposes. For example, if the mitochondria are being purified to isolate mitochondrial DNA, contamination with nuclei, not the small organelles, is a problem and the following modifications could be made: Harvest the cells in stationary growth phase when the fewest cells will be actively dividing, substitute $\mathrm{CaCl}_{2}$ for $\mathrm{MgCl}_{2}$ in the RSB hypo buffer to stabilize the nuclear membrane, omit washing the mitochondrial pellet, omit any density gradient purification, resuspend and lyse the mitochondrial pellet from Step 10, and purify the mitochondrial DNA from any remaining nuclear DNA (Hudson et al. 1968).

\section{RECIPES}

MS Homogenization Buffer (1×)

210 mM mannitol

$70 \mathrm{~mm}$ sucrose

$5 \mathrm{~mm}$ Tris- $\mathrm{HCl}(\mathrm{pH} 7.5)$

1 mм EDTA (pH 7.5)

The buffer should be ice cold before use.

MS Homogenization Buffer (2.5×)

525 mM mannitol

$175 \mathrm{~mm}$ sucrose

$12.5 \mathrm{~mm}$ Tris- $\mathrm{HCl}(\mathrm{pH} 7.5)$

$2.5 \mathrm{~mm}$ EDTA (pH 7.5)

The buffer should be ice cold before use.

RSB Hypo Buffer

$10 \mathrm{~mm} \mathrm{NaCl}$

$1.5 \mathrm{~mm} \mathrm{MgCl}_{2}$

$10 \mathrm{~mm}$ Tris- $\mathrm{HCl}(\mathrm{pH} 7.5)$

The buffer should be ice cold before use.

\section{REFERENCES}

Clayton DA, Shadel GS. 2014. Purification of mitochondria by sucrose step density gradient centrifugation. Cold Spring Harb Protoc doi: 10.1101/ pdb.prot080028.

Frezza C, Cipolat S, Scorrano L. 2007. Organelle isolation: Functional mitochondria from mouse liver, muscle and cultured fibroblasts. Nature Protocols 2: 287-295.
Hudson B, Clayton DA, Vinograd J. 1968. Complex mitochondrial DNA. Cold Spring Harbor Symp Quant Biol 33: 435-442. 


\section{Isolation of Mitochondria from Tissue Culture Cells}

David A. Clayton and Gerald S. Shadel

Cold Spring Harb Protoc; doi: 10.1101/pdb.prot080002

\begin{tabular}{rc}
$\begin{array}{r}\text { Email Alerting } \\
\text { Service }\end{array}$ & Receive free email alerts when new articles cite this article - click here. \\
\hline $\begin{array}{r}\text { Subject } \\
\text { Categories }\end{array}$ & $\begin{array}{c}\text { Browse articles on similar topics from Cold Spring Harbor Protocols. } \\
\text { Cell Biology, general (1382 articles) } \\
\text { Subcellular Fractionation (88 articles) }\end{array}$ \\
\hline
\end{tabular}

